\title{
Adhesive molecules and inflammatory markers among hepatitis C virus Saudi patients
}

\begin{abstract}
Osama H. Al-J iffri ${ }^{1}$
ABST RACT

Background: Currently, about $2 \%$ of population are affected with hepatitis $\mathrm{C}$ worldwide, chronic hepatitis $\mathrm{C}$ ( $\mathrm{CHC}$ ) is the major cause of hepatic cirrhosis and referral for liver transplant. However, there is a high need for noninvasive methods for assessment of hepatocellular damage.

Objective: The purpose of this study was to determine the strength of the association between adhesive molecules and inflammatory markers among hepatitis $\mathrm{C}$ virus Saudi patients.

Methods: One hundred patients with chronic hepatitis C virus infection(64 males and 36 females, their age ranged from 28 to 53 years with circulating anti-HCV antibodies were equally categorized into two study groups: patients with $\mathrm{CHC}$ and patients with liver cirrhosis (LC). Also, one fifty healthy subjects were included as healthy controls. Serum alanine aminotransferase (ALT), soluble intercellular adhesion molecule1 (sICAM-1); Soluble vascular adhesion molecule 1(sVCAM-1); Soluble E-selectin(s-E-selectin) and Tumor necrosis factor-alpha (TNF-a) were assayed for all participants. Results: We observed elevation with regard to the healthy controls group in the parameters of ALT, sICAM-1, SVCAM-1, s-E-selectin and TNF-a for patients with CHC and patients with liver cirrhosis (LC). Also, a significant positive correlation between serum TNF-a, sICAM-1, SVCAM-1 and ALT values was detected.

Conclusion: In conclusion, our results confirm that, in patients with chronic virus hepatitis and liver cirrhosis there is a significant positive correlation between serum TNF-a, sICAM-1, sVCAM-1 and ALT values. These findings suggest that serum TNF-a levels could be used as a sensitive predictor of liver inflammation, while serum ICAM-1 can be considered as a marker of hepatic necrosis and inflammatory activity in chronic hepatitis, while serum VCAM-1 is an indicator for the severity of liver cirrhosis.
\end{abstract}

Keywords: adhesive molecules, inflammatory markers, chronic hepatitis C, liver cirrhosis

\section{INTRODUCTION}

Chronic hepatitis $\mathrm{C}(\mathrm{CHC})$ is a global health problem, that affects over $3 \%$ of global population (1) and 3 to 4 million are newly infected each year $(2,3)$ with an estimated 180 million people infected worldwide (4). Hepatitis C virus (HCV) infection is one of the main causes of chronic liver disease worldwide (5) and persistent infection occurs in 50 to $80 \%$ of those infected and may lead to the development of cirrhosis and subsequent hepatocellular carcinoma $(2,6)$. In most cases of HVC infection, the host immune system fails to eradicate the virus and a sustained immune-inflammatory response takes place. Besides its ineffectiveness to eliminate HCV, the immune response also damages the liver tissue, leading to inflammation, fibrosis, and hepatocellular alterations (1).

Liver damage in chronic hepatitis $\mathrm{C}(\mathrm{CHC})$ is commonly attributed to immune-mediated mechanisms (7). Hepatic fibrosis is characterized by abnormal excessive accumulation of extracellular matrix accompanied by exaggerated cytokine release, However recruitment and trans-differentiation of peripheral blood cells, in particular, monocytes into injured liver may play a role in this respect (8). Chronic viral hepatitis is histologically characterized by intralobular infiltration of inflammatory cells which is considered as an ominous sign of deterioration and a criterion for disease activity (9).

Adhesion molecules are intimately involved in disease mechanisms of inflammation and cancers. Intercellular adhesion molecule-1 (ICAM-1) and leucocyte functionassociated antigen-1, a ligand for ICAM-1, play a critical role in the interactions of cytotoxic T cells both with target cells and with other immune cells (10). Vascular cell adhesion molecule-
1 (VCAM-1) is important in the extravasation of circulating lymphocytes and in their infiltration into inflamed sites (11, 12). ICAM-1 is overexpressed in sinusoidal endothelial cells in liver tissues with hepatitis. Hepatocytes at the site of inflammation express ICAM-1 $(13,14)$. Recently developed enzymelinked immunosorbent assays (ELISA) for soluble forms of ICAM-1 ( $I$ ICAM-1) and VCAM-1 (sVCAM-1) in serum are useful for monitoring chronic hepatitis and hepatocellular carcinoma $(15,16)$.

ICAM-1 and VCAM-1 are strongly expressed on sinusoidal lining cells in chronic hepatic inflammation due to HCV infection and play a key role in leukocyte recruitment and extravasation (17). Moreover, it was found that HCV-infected hepatocytes but not normal hepatocytes express ICAM-1 (18). However, ICAM-1 has a restricted tissue distribution (19), but its expression can be up-regulated in response to proinflammatory cytokines as tumor necrosis factor-al pha (TNFa) on various cells including hepatocytes (20).

Tumor necrosis factor-alpha (TNF- $\alpha$ ) is a proinflammatory cytokine with a major role in both acute and chronic responses to viral, bacterial, fungal and parasitic infections (21). TNF- a is produced primarily by activated macrophages during the inflammatory reaction that follows recognition of viral antigens, but the precise stimulus for its enhanced production in HCV infection has not been clearly defined (22). TNF- a has been involved in the pathogenesis of several liver conditions including viral hepatitis (23). In patients with hepatitis C, TNF$a$ is an inducer of apoptosis in infected hepatocytes (24) and might also account for CTL damage to nearby non-infected hepatocytes (25).
1 Department of Medical Laboratory Technology, Faculty of Applied Medical Sciences, King Abdulaziz University, Saudi Arabia

Received: 03 J an 2016, Accepted: 17 March 2016
Correspondence: Dr. Osama H. Al-J iffri

Faculty of Applied Medical Sciences, King Abdulaziz University, Saudi Arabia Postal code: 21589

Phone: +9665002878 .

E-mail: Dr_jiffri1@outlook.com 
Table 1: Comparison of clinical data between healthy controls, patients with HCV infected individuals with or without cirrhosis

\begin{tabular}{|c|c|c|c|}
\hline & $\begin{array}{l}\text { Healthy } \\
\text { controls }\end{array}$ & $\begin{array}{l}\text { CHC without } \\
\text { cirrhosis }\end{array}$ & $\begin{array}{l}\text { CHC with } \\
\text { cirrhosis }\end{array}$ \\
\hline Age (year) & $48.96 \pm 5.18$ & $50.73 \pm 4.24$ & $49.16 \pm 5.71$ \\
\hline $\mathrm{BMI}\left(\mathrm{kg} / \mathrm{m}^{2}\right)$ & $28.15 \pm 2.23$ & $27.65 \pm 2.46$ & $27.18 \pm 3.12$ \\
\hline Waist circumference $(\mathrm{cm})$ & $82.51 \pm 7.19$ & $80.31 \pm 6.52$ & $82.13 \pm 5.84$ \\
\hline Fat mass $(\mathrm{kg})$ & $18.35 \pm 2.44$ & $17.98 \pm 3.78$ & $16.67 \pm 2.81$ \\
\hline FPG $(\mathrm{mg} / \mathrm{dl})$ & $112.81 \pm 18.54$ & $116.50 \pm 14.16$ & $119.45 \pm 13.95$ \\
\hline $\mathrm{Hb}(\mathrm{gm} / \mathrm{dl})$ & $13.46 \pm 1.82$ & $11.25 \pm 1.71$ & $10.19 \pm 1.93$ \\
\hline AST (IU/I) & $30.76 \pm 5.22$ & $45.25 \pm 8.91^{*}$ & $81.73 \pm 11.17 * \$$ \\
\hline Albumin $(\mathrm{gm} / \mathrm{dl})$ & $4.15 \pm 0.65$ & $3.42 \pm 0.58^{*}$ & $2.25 \pm 0.41^{* \$}$ \\
\hline Total Bilirubin (mg/dl) & $0.62 \pm 0.18$ & $1.23 \pm 0.37 *$ & $2.76 \pm 0.95 * \$$ \\
\hline
\end{tabular}

The aim of this study was to determine the strength of the association between adhesive molecules and inflammatory markers among hepatitis $C$ virus Saudi patients.

\section{SUBJ ECTS AND METHODS}

One hundred patients ( 64 males and 36 females, their age ranged from 28 to $53(42.26 \pm 5.17)$ years, were studied upon referral to Gastroenterology and Hepatology Department, King Abdulaziz University Teaching Hospital, Saudi Arabia. All these patients were anti HCV positive by enzyme-linked immunosorbent assay (ELISA). None of the patients included in this study had other potential causes of liver disease, such as alcoholism, autoimmune phenomena, or metabolic disorders. All participants had $\mathrm{CHC}$ infection with circulating anti-HCV antibodies and were equally categorized into two study groups: patients with $\mathrm{CHC}$ and patients with liver cirrhosis (LC). Patients diagnosis and classification were based on detailed medical history, thorough clinical examination, kidneys and liver function tests, procto-sigmoidoscopy, abdominal ultrasonography, parasitological examination and liver biopsies. None of the subjects gave history of medication with interferon and ribavirin or drugs known to have influence on the coagulation process within 8 weeks of study time or had a renal impairment based on normal creatinine clearance. However, one fifty healthy subjects were included as healthy controls. This study was approved by the Scientific Research Ethical Committee, Faculty of Applied Medical Sciences at King Abdulaziz University. All participants were free to withdraw from the study at any time.

\section{Laboratory Analysis}

Ten milliliter blood samples were collected from each participant at study entry. The blood samples were obtained using disposable needles and heparinized vacuum syringes and stored at $-70^{\circ} \mathrm{C}$ until assayed. Serum levels of aspirate aminotransferase (AST) and alanine aminotransferase (ALT) by serum chemistry autoanalyzer (Model 736, Hitachi, Tokyo, J apan) using commercial reagents (Biomerieux, Marcy L'Etoile, France). However, Serum ICAM-1, VCAM-1 and E- Selectin located to the cell surface were measured after fixation with $4 \%$ formaldehyde and staining with anti-ICAM-1-FITC, antiVCAM-1-FITC, anti-p-selectin-RPE and anti-Tissue-factor-FITC or the corresponding FITC- or RPE-labeled negative controls by a FACSCanto II flow cytometer (Becton Dickinson, USA). Also, tumor necrosis factor-alpha (TNF-a) level was measured from frozen plasma samples stored at $-80^{\circ} \mathrm{C}$. Enzyme-linked immunosorbent assays kits (ELISAs) were used to measure soluble levels of TNF-a (GE Healthcare Amersham, Biotrak Easy ELISA), which utilized the quantitative sandwich enzyme immunoassay technique.
Table 2: Mean value and significance of SICAM-1, SVCAM-1, sEselectin and TNF- $a$ of healthy controls, patients with HCV infected individuals with or without cirrhosis

\begin{tabular}{|c|c|c|c|}
\hline & $\begin{array}{l}\text { Healthy } \\
\text { controls }\end{array}$ & $\begin{array}{l}\text { CHC without } \\
\text { cirrhosis }\end{array}$ & $\begin{array}{l}\text { CHC with } \\
\text { cirrhosis }\end{array}$ \\
\hline ALT (IU/I) & $31.26 \pm 6.37$ & $42.54 \pm 7.21$ & $49.91 \pm 7.61$ \\
\hline SICAM-1 ( $\mathrm{ng} / \mathrm{ml})$ & $213.65 \pm 21.18$ & $682.17 \pm 65.32^{*}$ & $1012.43 \pm 76.83^{* 5}$ \\
\hline SVCAM-1 (ng/ ml) & $338.74 \pm 25.77$ & $1355.16 \pm 57.23^{*}$ & $1763.19 \pm 82.46^{* 5}$ \\
\hline sE-selectin (ng/ ml) & $40.39 \pm 7.26$ & $94.81 \pm 12.42^{*}$ & $116.27 \pm 17.14^{* \$}$ \\
\hline TNF- $\mathrm{a}(\mathrm{pg} / \mathrm{ml})$ & $13.52 \pm 3.63$ & $32.26 \pm 6.13^{*}$ & $75.16 \pm 9.29 * \$$ \\
\hline $\begin{array}{l}\text { ALT: Alanine am } \\
\text { molecule1; sVCAM- } \\
\text { E-selectin; TNF-a: } \\
\text { difference relative } \\
\text { relative to } \mathrm{CHC}, \mathrm{P}\end{array}$ & $\begin{array}{l}\text { ansferase; } \\
\text { uble vascul } \\
\text { or necrosis } \\
\text { ealthy cont }\end{array}$ & $\begin{array}{l}\text { 1: Soluble } \\
\text { sion molecule } \\
\text {-alpha; }(*) \text { : }\end{array}$ & llular adhes \\
\hline
\end{tabular}

Table 3: Shows the Pearson's correlation coefficients test value and the relationship between ALT and SICAM-1, SVCAM1 , sE-selectin and TNF- $a$ in CHC patients with cirrhosis group than $\mathrm{CHC}$ patients without cirrhosis group

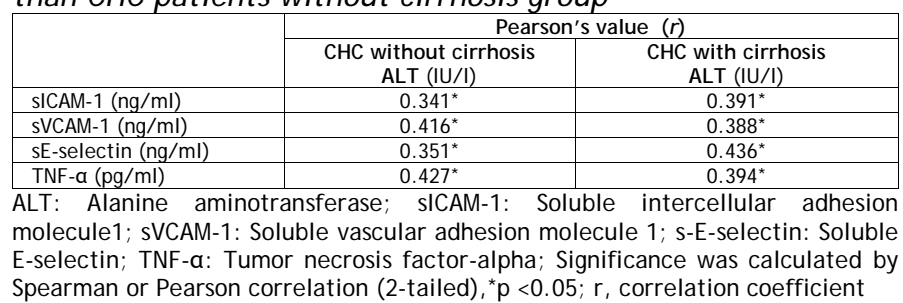

\section{Statistical Analysis}

Statistical analysis of data was performed using SPSS (Chicago, IL, USA) version 17. Means of different groups were compared using one-way ANOVA. The relationship between continuous variables and ALT was assessed by Pearson or Spearman rank correlation. All data were expressed as the mean \pm SD. $P<0.05$ indicated statistical significance.

\section{RESULTS}

The demographic and clinical characteristics of the all participants are shown in Table 1. The mean age of the healthy controls group was $48.96 \pm 5.18$ years, and the mean age of the $\mathrm{CHC}$ without cirrhosis group was $50.73 \pm 4.24$ years, where the mean age of the $\mathrm{CHC}$ with cirrhosis group was $49.16 \pm 5.71$ years. There was no significant age, body mass index, waist circumference, fat mass, fasting blood glucose and hemoglobin between the three groups. However, aspartate aminotransferase, albumin and total bilirubin were significantly different between the healthy controls, $\mathrm{CHC}$ without cirrhosis and $\mathrm{CHC}$ with cirrhosis groups.

The mean values of alanine aminotransferase, soluble intercellular adhesion molecule1, soluble vascular adhesion molecule 1, soluble E-selectin and tumor necrosis factor-alpha were significantly elevated in $\mathrm{CHC}$ patients with cirrhosis group and $\mathrm{CHC}$ patients without cirrhosis group when compared with Healthy controls group. Also, these parameters were significantly elevated in $\mathrm{CHC}$ patients with cirrhosis group than CHC patients without cirrhosis group (Table 2). The Pearson's correlation coefficients test for the relationship between Alanine aminotransferase and SICAM-1, SVCAM-1, SE-selectin and TNF- $\mathrm{a}$ in $\mathrm{CHC}$ patients with cirrhosis group than $\mathrm{CHC}$ patients without cirrhosis group showed a strong direct relationship (Table 3).

\section{DISCUSSION}

At present, the most reliable determination of severity and prognosis in chronic viral hepatitis is the histological staging of the disease which is an invasive procedure that is often not well accepted by patients. The search for alternative non-invasive methods is mandatory especially in follow-up after initial assessment by biopsy (26). Some authors reported that 
circulating levels of adhesive molecules are related to degree of inflammatory activity and to histological score, suggesting a putative role in monitoring the follow-up $(27,28)$. Others have declared that their measurement adds little to the information provided by traditional biochemistry (29). The aim of this study was to determine the strength of the association between adhesive molecules and inflammatory markers among hepatitis $C$ virus patients.

The results of our present paper showed that TNF-a levels in patients with chronic HCV and patients with liver cirrhosis are higher than in healthy controls. Thus, demonstrating that $\mathrm{HCV}$ individuals have a characteristic inflammation as compared to the normal population. Therefore, we proposed TNF- $a$ as a marker of sustained response for the HCV population undergoing standard therapy. These results are in line with other studies as Neuman et al. who reported that serum TNF-a levels are significantly higher among patients with $\mathrm{CHC}$ compared to healthy volunteers (30). Also, Fallahi et al. stated that production of inappropriate levels of IL- 6 and tumor necrosis factor-alpha (TNF- $a$ ) has been associated with the progression of chronic hepatitis C (31). However, Shapiro et al. proved that cytokines have been associated with liver inj ury in $\mathrm{HCV}$ and there is evidence that they can also be linked with response to therapy (32). Moreover, Neuman et al. demonstrated a correlation between TNF- $a$ levels and the severity of HCV and the significance of TNF-a levels as mediators of inflammation, thus suggesting an immunemediated response (33).

Moreover, our results also revealed marked elevation in circulating levels of soluble adhesive molecules sE-selectin, SICAM-1 and SVCAM-1 in both groups of patients with chronic hepatitis $C$ liver disease compared to controls. Many previous studies reported increased SICAM- 1 and SVCAM- 1 values in patients with inflammatory diseases of the liver (34-38). While, elevated serum VCAM- 1 in chronic hepatitis have been reported by some authors $(39,40)$. Also, many authors confirmed our data related to higher levels of SICAM-1 among patients with chronic HCV-related hepatitis than do control subjects $(28,41$, 42). Moreover, similar results are reported in patients with CLD (34) and $\mathrm{CHC}(18,25)$.

Our results also revealed marked elevation in circulating levels of ICAM- 1 and VCAM- 1 in cirrhotic patients compared to non-cirrhotic cases. Enhanced levels of these adhesion molecules may be the consequence of persistent activation of vascular endothelial cells which are able to produce connective tissue growth factor, a highly profibrogenic molecules involved in several fibrotic disorders, including those of the liver (43).

\section{REFERENCES}

1. Lefkowitch JH. Liver biopsy assessment in chronic hepatitis. Arch Med Res. 2007;38:634.

2. Rosen HR. Clinical practice. Chronic hepatitis C infection. N Engl J Med. 2011;364:2429-38.

3. Sheridan D, Neely R, Bassendine M. Hepatitis C virus and lipids in the era of direct acting antivirals (DAAs) Clinics and Research in Hepatology and Gastroenterology. 2013; 37(1): 10-16.

4. National Institute of Allergy and Infectious Diseases. Hepatitis C. 2011. Available from: http:// www. niaid. nih.gov/ topics/ hepatitis/ hepatitisc/ Pages/ Default.aspx. Accessed December 12, 2013.

5. European Association for the Study of the Liver: EASL Clinical Practice Guidelines: Management of hepatitis $C$ virus infection. J ournal of Hepatology. 2014;60:392-420.
Such elevation in circulating ICAM- 1 and VCAM- 1 levels may be also attributed to increased levels of pro-inflammatory cytokines as TNF- $a$ which was also reported in our study. TNF$a$ is a potent mediator of inflammation and sepsis (44) and has a pleiotropic effect on a wide variety of cells including endothelial cells (45). Furthermore, data revealed the circulating levels of TNF- $\alpha$ in both groups of patients were strongly correlated with each of SICAM- 1 and SVCAM-1 values in these patients. These findings indicate that TNF- $a$ might directly induce the expression of ICAM- 1 and VCAM- 1 in vascular endothelial cells (44).

Moreover, we found a significant positive correlation between adhesive molecules and ALT values. Then, our findings appear in agreement with literature data and suggest that VCAM-1, which is considered to reflect the degree of liver fibrosis $(25,28)$ and ICAM- 1 levels, markers of liver inflammation, have significantly decreased in HCV patients with normal ALT levels following interferon administration $(28,42,46,47)$. However, the relationship between ICAM-1, VCAM- 1 and ALT values does not implicate a direct involvement of these adhesion molecules in physiopathology of hepatocellular damage, but it could only reflect the activation of undergoing immunological mechanisms.

Concerning the relationship between TNF-a levels and ALT, we found a positive relationship between them, these results are in line with Hassan et al. proved a positive relationship between TNF-a levels and aminotransferase levels (48), also Neuman et al. stated that TNF-a levels significantly decreased at the end of treatment and the decline paralleled those observed with aminotransferase levels (30). However, DuranteMangoni et al. found an elevated serum levels of TNF-a have also been associated with hepatic steatosis (49). Moreover, Tilg et al. proved a positive correlation between TNF-a levels and inflammation and fibrosis in liver biopsies (50).

\section{CONCLUSION}

In conclusion, our results confirm that, in patients with chronic virus hepatitis and liver cirrhosis there is a significant positive correlation between serum TNF- $a$, adhesive molecules and ALT values. These findings suggest that serum TNF-a levels could be used as a sensitive predictor of liver inflammation, while serum ICAM-1 can be considered as a marker of hepatic necrosis and inflammatory activity in chronic hepatitis, while serum VCAM-1 is an indicator for the severity of liver cirrhosist.

6. Hanafiah KM, Groeger J, Flaxman AD, Wiersma ST. Global epidemiology of hepatitis $C$ virus infection: new estimates of age-specific antibody to $\mathrm{HCV}$ seroprevalence. Hepatology. 2013; 57:1333-42.

7. Spengler $U$, Nattermann J. Immunopathogenesis in hepatitis C virus cirrhosis. Clin Sci (Lond) 2007; 112:14155.

8. Ruhnke M, Nussler AK, Ungefroren $\mathrm{H}$. Human monocytederived neohepatocytes: a promising alternative to primary human hepatocytes for autologous cell therapy. Transplantation. 2005; 79:1097-103.

9. Harvey EC, Post J J, Palladinetti P, Freeman J A, Ffrench RA, Kumar RK, Marinos G, Lloyd AR. Expression of the chemokine IP-10 (CXCL10) by hepatocytes in chronic hepatitis $C$ virus infection correlates with histological severity and lobular inflammation. J Leuk Biol. 2003; 74:360-369. 
10. Makgoba MW, Sanders ME, Ginther-Luce GE. Functional evidence that intercellular adhesion molecule-1 (ICAM1 ) is a ligand for LFA-I in cytotoxic T cell recognition. EUT J Immuno1. 1988; 18: 636-640.

11. Hemler ME, Elices MJ , Parker C. Structure of the integrin VLA-4 and its cell-cell and cell-matrix adhesion functions. Immunol Rev. 1990; 114:45-65.

12. Postig6 AA, Teixid6 J, Sanchez-Madrid F. The CX41311VCAM-1 adhesion pathway in physiology and disease. Res Immuno1. 1994; 144: 723-735.

13. Volpes $R$, van Den Oord II, Desmet VJ . Immunohistochemical study of adhesion molecules in liver inflammation. Hepatology. 1990; 12:59-65.

14. Horiike $\mathrm{N}$, Onji $\mathrm{M}$, Kumon I. Intercellular adhesion molecule-1 expression on the hepatocyte membrane of patients with chronic hepatitis Band C. Liver. 1993; 13:10-14.

15. Marui A, Fukuda Y, Koyama Y. Serum levels of soluble intercellular adhesion molecule-I and soluble vascular cell adhesion molecule-I in liver disease, and their changes by treatment with interferon. J Int Med Res. 1995; 24:258-265.

16. Horiike N, Onji M, Kumamoto I. Soluble intercellular adhesion moleculel in serum in chronic hepatitis Band C. J Gastroentero. 1994; 29:455-459.

17. Ala A, Dhillon AP, Hodgson HJ. Role of cell adhesion molecules in leukocyte recruitment in the liver and gut. Int J Exp Pathol. 2003; 84: 1-16.

18. El-Bassiouni NE, El Bassiouny AE, El Sherif NH, Akl MM, Hussein AT, Omran SA. Soluble adhesion molecules in chronic hepatitis $C$ and cirrhosis: preferential release. J of Hepatol, Gastroentrol and Infect Dis. 1999;6:55-66.

19. Simpson KJ, Hayes PC. Soluble adhesion molecules in immune mediated liver disease. Gut. 1995; 36:806-8.

20. Adams DH, Mainolfi E, Burra P. Detection of circulating intercellular adhesion molecule-1 in chronic liver disease. Hepatology. 1992;16:810-4.

21. Bradley JR. TNF-mediated inflammatory disease. J Pathol. 2008;214:149-60.

22. Radkowski M, Bednarska A, Horban A. Infection of primary human macrophages with hepatitis $C$ virus in vitro: induction of tumour necrosis factor-alpha and interleukin 8. J Gen Virol. 2004; 85:47-59.

23. Kallinowski $B$, Haseroth $K$, Marinos $G$. Induction of tumour necrosis factor (TNF) receptor type p55 and p75 in patients with chronic hepatitis $\mathrm{C}$ virus (HCV) infection. Clin Exp Immunol. 1998; 111:269-77.

24. Kountouras J, Zavos C, Chatzopoulos D. Apoptosis in hepatitis C. J Viral Hepat. 2003;10:335-42.

25. Kaplanski G, Farnarier C, Payan MJ. Increased levels of soluble adhesion molecules in the serum of patients with hepatitis C. Correlation with cytokine concentrations and liver inflammation and fibrosis. Dig Dis Sci. 1997; 42:2277-84.

26. El-Gohary AM, Fawaz N A, Hassoba HM, Serwah A, Ali M. Soluble ICAM-1 in patients with chronic hepatitis $C$ infection: a prognostic marker of disease activity. Egypt J Immunol. 2004; 11(2):109-19.

27. Douds AC, Lim AG, J azrawi RP, Finlayson C, Maxwell DJ . Serum intercellular adhesion molecule-1 in alcoholic liver disease and its relationship with histological disease severity. J Hepatol. 1997;26: 280-286.

28. Lo lacono O, Garcia-Monzon C, Almasio P, Garcia-Buey L, Craxì A, Moreno-Otero R. Soluble adhesion molecules correlate with liver inflammation and fibrosis in chronic hepatitis C treated with interferon-a. Aliment Pharmacol Ther. 1998; 12: 1091-1099.
29. Falleti E, Pirisi M, Fabris C, Bortolotti N, Soardo G, Gonano F, Batoli E. Circulating standard CD44 isoform in patients with liver disease: relationship with other solubile adhesion molecules and evaluation of diagnostic usefulness. Clinical Biochemistry. 1997;30:69-73.

30. Neuman MG, Benhamou JP, Malkiewicz IM. Cytokines as predictors for sustained response and as markers for immunomodulation in patients with chronic hepatitis $C$. Clin Biochem. 2001;34:173-82.

31. Fallahi P, Ferri C, Ferrari SM, Corrado A, Sansonno D, Antonelli A. Cytokines and HCV-related disorders. Clin Dev Immunol. 2012;468107: 1-10.

32. Shapiro S, Gershtein V, Elias N, Zuckerman E, Salman N, Lahat N. mRNA cytokine profile in peripheral blood cells from chronic hepatitis $\mathrm{C}$ virus (HCV)-infected patients: effects of interferon-alpha (IFN-alpha) treatment. Clin Exp Immunol. 1998; 114(1): 55-60.

33. Neuman MG, Benhamou JP, Martinot M. Predictors of sustained response to alpha interferon therapy in chronic hepatitis C. Clin Biochem. 1999; 32:537-45.

34. Giron-Gonzalez J A, Rodriguez-Ramos C, Elvira J, Galan F, Del Alamo CF, Diaz F, Martin-Herrera L. Serial analysis of serum and ascitic fluid levels of soluble adhesion molecules and chemokines in patients with spontaneous bacterial peritonitis. Clin Exp Immunol. 2001;123:56-61.

35. Thomson AW, Satoh S, Nussler AK, Tamura K, Woo J, Gavaler J, van Thiel DH. Circulating intercellular adhesion molecule-1 (ICAM-1) in autoimmune liver disease and evidence for the production of ICAM-1 by cytokine-stimulated human hepatocytes. Clin Exp Immunol. 1994; 95: 83-90.

36. Tortorella C, Sacco R, Orlando P, Salerno MT, Schiraldi 0 , Antonaci S. sICAM-1, SCD95 and SCD95L levels in chronic liver diseases of different etiology. Immunopharmacol Immunotoxicol. 2000;22:19-33.

37. de Caestecker JS. Bile acid therapy and markers of immunemediated damage in primary biliary cirrhosis. Eur J Gastroenterol Hepatol. 1997; 9: 145-147.

38. Granot E, Shouval D, Ashur Y. Cell adhesion molecules and hyaluronic acid as markers of inflammation, fibrosis and response to antiviral therapy in chronic hepatitis $C$ patients. Mediators Inflamm. 2001; 10: 253-258.

39. Dejica D, Grigorescu M, Dejica V, Radu C, Neculoiu D. Serum levels of soluble intercellular-1 and vascular cell1 adhesion molecules in chronic hepatitis $C$ and the influence of interferon-alpha + ribavirin therapy. Rom J Gastroenterol. 2002; 11:277-283.

40. Kaplanski G, Farnarier C, Payan MJ , Bongrand P, Durand J M. Increased levels of soluble adhesion molecules in the serum of patients with hepatitis $C$. Correlation with cytokine concentrations and liver inflammation and fibrosis. Dig Dis Sci. 1997;42:2277-2284.

41. Seth R, Raymond FD, Makgoba MW. Circulating ICAM-1 isoforms: diagnostic prospects for inflammatory and immune disorders. Lancet. 1991; 338:83-4.

42. Bagnasco M, Riccio AM, Sinelli M. Serum intercellular adhesion molecule-1 and long-term response to IFN-a-2B therapy in chronic hepatitis C. J Interferon Cytokine Res. 1998; 18: 963-6.

43. Rachfal AW, Brigstock DR. Connective tissue growth factor (CTGF/CCN2) in hepatic fibrosis. Hepatol Res. 2003; 26: 1-9.

44. Beutler B, Cerami A: Cachectin. More than a tumor necrosis factor. New Eng J Med. 1987;316:379-386.

45. Philippe J, Dooijewaard G, Offner F, Turion P, Baele G, Leroux-roels G. Granulocyte elastase, tumor necrosis factor- $\alpha$ and urokinase levels as prognostic markers in severe infection. Thromb Haemost. 1992;68: 19-23. 
46. Gattoni A, Romano C, Cecere A. Serum levels of soluble intercellular adhesion molecule 1 (sICAM-1) as a potential marker of disease activity and remission in patients with chronic hepatitis C. Paninerva Med. 1997; 39: 256-262.

47. Capra F, Demaria E, Lunardi C. Serum level of soluble intercellular adhesion moelcule 1 in patients with chronic liver disease related to hepatitis C virus: a prognostic marker for responses to interferon treatment. J Infect Dis. 2000; 181:425-431.
48. Hassan Ml, Kassim SK, Ahmad Ml, Fawzy S. Antiproliferative effect of hepatitis $C$ virus on mitogenstimulated peripheral blood mononuclear cells: potential role in viral persistence in Egyptian patients. Clin Biochem. 2007; 40:1173-9.

49. Durante-Mangoni E, Zampino R, Marrone A. Hepatic steatosis and insulin resistance are associated with serum imbalance of adiponectin/ tumour necrosis factoralpha in chronic hepatitis $\mathrm{C}$ patients. Aliment Pharmacol Ther. 2006;24:1349-57.

50. Tilg H, Vogel W, Dinarello CA. Interferon-alpha induces circulating tumor necrosis factor receptor p55 in humans. Blood. 1995;85:433-5.

\section{$\diamond \diamond \diamond \diamond \diamond \diamond \diamond$}

http:/ / www.ejgm.org 